\title{
The Interrelationships Of Innovation, Change, Originality, And Creativity
}

\author{
Gillian Coote Martin, South Florida Career College, USA
}

\begin{abstract}
People often assume that innovation is synonymous with originality. However, a study reveals a difference between innovation and creativity in relation to how a person uses originality to create change. Creative people think of new phenomena; innovative people create new things. In today's world, innovation is the focal point of every organization. In order to be successful in innovation, companies must constantly ask questions to capture the consumer's point of view.
\end{abstract}

Keywords: Innovation; Change; Originality; Creativity

\section{INTRODUCTION}

nnovation is a change that crafts new elements of implementation. Every leader should know how to
establish a creative work environment, provide the right tools, and determine the probabilities to make
innovation an ingredient of the organization's everyday design. Leaders must be thorough in explaining why it is critical for their teams to discontinue practices that are no longer effective.

Innovation concentrates on the organization and its chief fundamentals. It must formulate things to simplify the function of the organization. If not, it is not innovation, but impediment. Innovation helps an organization to identify and create its individuality. In that regard, most people think of innovation as the paramount skill. Innovation creates an elevated level of force in every organization that inspires and develops it. This force, in turn, fosters change and growth in each person in the organization: employees, consumers, merchants and shareholders. In an innovative organization, everybody grows and has creativity (Vennat, 2002).

\section{INNOVATION}

Innovation is important for every business, no matter how large or small, that desires to survive. For small businesses, innovation does not indicate the development of new technologies, but the capability to distinguish opportunities to implement them and put them into work. To small businesses, innovation signifies growth, improvement and profitability for a segment that is the principal driver of the economy and employment growth (Vennat, 2002). In this context, this researcher thinks of innovation as the most important skill. Innovation elevates the energy level of every organization that nurtures, feeds, and encourages it. This energy feeds everybody the organization touches: employees, consumers, merchants, lenders, and investors. Innovation is important to all of these groups.

Innovation is essential to all sectors of today's economy - the modern and the long-established - not just to high-tech or biotech, but to all segments including manufacturing, mining, farming and service industries (Vennat, 2002). The significance of managing innovation has been growing with increasing awareness of its influence on competitiveness. A study describes competitiveness as the capability of companies and industries to create comparatively key factors of employment levels on a sustainable basis, while remaining exposed to global competition (Bhat, 2010). 


\section{THE IMPORTANCE OF INNOVATION}

An organization's supplies and capabilities consist of all the monetary and organizational assets an organization uses to improve, produce and deliver products and services to the consumer (Bhat, 2010). The knowledge base of an organization is the accumulation of the knowledge bases of all individuals within an organization and the social knowledge those individuals embed within their relationships (Bhat, 2010). These relationships are often what shape organizational processes and procedures. Throughout these organizational processes, individual knowledge contributes to a better body of knowledge the organization can access as a whole, leading to progressive competences. Research has shown that the knowledge base of an organization will be better than the total of the individual knowledge bases because social and organizational relationships often affect knowledge (Bhat, 2010).

\section{CHANGE}

Change is the leading constant in today's busy world. Many organizations are finding that they have to innovate constantly not only to compete for substantial profits, clients, and shareholders, but also to remain pertinent to the changes around them. Often, individuals oppose change because it can be a terrifying procedure when most, if not everything, is undergoing change. Change development is an assertive process requiring a total group effort of responsibility and collaboration from all employees and organization stakeholders.

The paramount step in the change process is identifying the problematic. Managers must detect and characterize problems to determine what needs to be changed and what goals should be set (Plunkett, 2008). Next, the company must find suitable contingency plans, make note of historical and contemporary change proposals, and determine which change techniques to use. Evaluating the probability of change is the second step. This step involves determining leadership, assessing the eagerness of the organization to make the change, and understanding the extent of change and the general impact of the change will have on the organization.

\section{THE IMPORTANCE OF CHANGE}

Implementing change is one of the most problematical steps in the change process. This step involves characterizing the socio-cultural, economic, technological, ethical, and political aspects of the business. It also involves determining the vision, goal, and significances of the organization. Organizations must choose educational, team, and personal options to create an inclusive program with training, while assembling a community of leaders to execute the change plan (Plunkett, et al., 2008). Distinguishing leaders of the corporation, both internal and external, that are behind the change is essential to ensuring readiness. It is fundamental for leaders of change to demonstrate that management are sincere in their efforts to change and that this endeavor is not just another failed agenda. This will help clarify benefits of change to all employees (Walker\& Bernerth, 2007). The change objective should clearly state benefits and describe the change process. For example, employees may be able to perform their jobs healthier, their pay scale might increase, or a longer duration of job security may result from the change. The capacity of the executive team to tackle these components is influential in the change objectives and an essential commitment to the change process (Walker\& Bernerth, 2007).

\section{SUMMARY}

Studies have established the essential steps leadership needs to take in order to implement innovation and change effectively. However, some researchers have attempted to incorporate the factors customary to all innovation and change efforts. Change and innovation have the competence to persuade the change success. In this analysis, the investigator assessed and accepted a paradigm that integrates all of the aforementioned innovation and change factors. Recognizing these relationships can assist management in the challenge to guarantee success. Potential research should try to examine the recommended relationships further. The recognition of these relationships can support and sustain successful plans and procedures. 


\section{AUTHOR INFORMATION}

Gillian Coote Martin is a Doctor in Business Administration Candidate at Argosy University, USA. E-mail: oneak200@msn.com

\section{REFERENCES}

1. Bhat, J. S. A. (2010). Managing innovation: Understanding how continuity and change are interlinked. Global Journal of Flexible Systems Management, 11(1), 63-73. Retrieved from http://search.proquest.com/docview/847640518?accountid=34899

2. Plunkett, W. R., Attner, R. F. \& Allen, G. S., (2008). Management: Meeting and Exceeding Customer Expectations (9th Ed.). Mason, OH: Thomson South-Western.

3. Vennat, M. (2002, The power of innovation: Driving small business growth. Canadian Speeches, 15(6), n/a-n/a. Retrieved from http://search.proquest.com/docview/222202646? accountid=34899

4. Walker, H. J., Armenakis, A. A., \& Bernerth, J. B. (2007). Factors influencing organizational change efforts. Journal of Organizational Change Management, 20(6), 761-773. doi:10.1108/09534810710831000 
International Journal of Management \& Information Systems - Third Quarter $2012 \quad$ Volume 16, Number 3

NOTES 